\title{
- Fear and Anxiety of COVID - 19 in a Disadvantaged Population in the San Juan De Lurigancho District of Lima \\ IICRR \\ Section: Healthcare
}

ISI Impact Factor (2020-21): 1.899

IC Value (2020): 91.47 SJIF (2020) $=7.893$

(c) (7) (8)

Copyright@IJCRR

\section{Rosa PS ${ }^{1 *}$, Hernan MS², Eduardo MS²}

'Perez-Siguas Rosa, Researcher, Research Directorate, Universidad María Auxiliadora, 15314, Lima-Perú; ${ }^{2}$ Research Directorate, Universidad María Auxiliadora, 15314, Lima-Perú.

\section{ABSTRACT}

Background: The fear and anxiety of COVID-19 is one of the factors that alter the mental health of the population, forcing them not to develop the capacity to cope in situations that compromise the health of their family

Objective: The objective is to determine the fear and anxiety to COVID - 19 in a disadvantaged population in the San Juan de Lurigancho district. It is a quantitative, correlational, non-experimental cross-sectional study, with a population of 617 participants, who answered a virtual questionnaire of sociodemographic data, the scale of fear of COVID - 19 and scale of anxiety due to COVID - 19.

Results: In its results the relationship between anxiety and fear of COVID - 19, where $218(48.8 \%)$ of the participants without dysfunctional anxiety presented a moderate effect on fear of COVID - 19 and in participants with dysfunctional anxiety 92 (54.1\%) presented a high effect on fear of COVID - 19.

Conclusions: It is concluded, strategies should be sought to address the consequences on the mental health of the population. Key Words: Pandemic, Coronavirus, Fear, Anxiety, Vulnerability

\section{INTRODUCTION}

Worldwide, the pandemic due to the new strain of coronavirus (COVID - 19) has globally alerted the whole world, where this deadly virus has spread in all countries generating infections and deaths, and causing a terrifying environment in the population, ${ }^{1,2}$ where fear and anxiety lead many people to suffer mental problems, ${ }^{3}$ over time, the population will witness psycho-emotional changes resulting from the COVID-19 disease and that can compromise their health either in the short or long term. ${ }^{4}$

I we expect similar outcomes as the ones showed in previous global pandemics, such as high levels of anxiety, fear, stress and post-traumatic stress to be evidenced in people, which, over time, cause severe sequelae in the mental health. ${ }^{5}$

It is expected that COVID-19 pandemic will generate a negative impact in the mental health of the population in underdeveloped countries, due to fear, anguish, anxiety and presenting symptoms of post-traumatic stress following seeing infected people, in poor general condition and deaths. ${ }^{6}$ To- day, the COVID-19 pandemic has already produced a high increase in mental health problems, since infections in the Perú and in the world started increasing. ${ }^{7}$

Likewise, quarantine, isolation, social distancing and loneliness at home are possible factors in increasing anxiety, stress and fear of being infected or that a family member may be positive. ${ }^{8,9}$ However, most people break quarantine because they do not have the necessary financial resources to cope, since, as a result of unemployment, it generates anxiety in the person, generating internal conflict within the home. ${ }^{10}$

In addition to this, the strict measures to prevent contagions at the home show the scarce resources to be able to stop it; where the vulnerability of people is increasing, to maintain the economy within the home and keep their families safe. ${ }^{11}$

In a study carried out in Germany, ${ }^{12}$ it was found in 15037 participants about anxiety and fear of COVID - 19, where the female sex presented high anxiety symptoms $29.8 \%$ than males $23.8 \%$ and fear of COVID - 19 with $62.9 \%$ than males $49.5 \%$.

\section{Corresponding Author:}

Perez-Siguas Rosa, Researcher, Research Directorate, Universidad María Auxiliadora, 15314, Lima-Perú. Ph:+51 996826968, Email: rosa.perez@uma.edu.pe

ISSN: 2231-2196 (Print)

Received: 12.04 .2021
ISSN: 0975-5241 (Online)

Revised: 23.05 .2021
Accepted: 13.07 .2022
Published: 01.03 .2022 
In a study conducted in India, ${ }^{13}$ it was evidenced in 217 participants that fear of COVID - 19 was highly related to gender, education and place, where high levels due to fear of COVID - 19 occurred more in females than in male sex, also, in the elderly population between 60 and 90 years old, they had a high level of fear of contracting COVID - 19.

In a study carried out in Germany, ${ }^{14}$ it was observed in its results of 16,245 participants that the fear of COVID-19 in $13.5 \%$ of the people with high fear had high anxiety and $7.2 \%$ of the participants with medium fear had moderate anxiety.

Therefore, this study will allow the search for strategies for the population to maintain balanced mental health to present adequate well-being, following then to demonstrate at home the ability to cope with this situation that compromises their health and their family.

The research work's objective is to determine the fear and anxiety of COVID-19 in a disadvantaged population in the San Juan de Lurigancho district.

\section{METHODOLOGY}

\section{Research type and Design}

Due to its characteristics, the present study has a quantitative approach to collecting data and measuring the variables involved Regarding the methodological design, it is a nonexperimental, correlational, cross-sectional study. ${ }^{15}$

\section{Population}

The total population is made up of 617 participants, who signed the informed consent for the study.

\section{Inclusion Criteria}

- People residing in a Human Settlement in San Juan de Lurigancho district.

- People over 18 years old.

- People who participate voluntarily and who have signed the informed content ACTA Nº39-2020-CE/ UMA UNIVERSIDAD MARIA AUXILIADORA.

\section{Technique and Instrument}

Data collecting instrument were virtual survey of the Google form, in which through the data collection instruments Fear of COVID - 19 Scale (FCV - 19S) and Coronavirus Anxiety Scale (CAS) that aim to determine fear and the anxiety of a disadvantaged population of San Juan de Lurigancho district of Lima (SJL).

For the data collection, it has been structured in 2 blocks: 1. Sociodemographic data such as age, sex, marital status, level of education, occupation; 2. FCV - 19S consist of 7 items in which it presents a one-dimensional dimension, in which it is ranked with a 5 point Likert scale: " $1=$ Totally disagree", " $2=$ Disagree", " $3=$ neither agree nor disagree", " $4=$ Agree " and " $5=$ Totally agree", obtaining a total score by adding all the items, so that score would range from 7 to 35 points, where" 7 to 16 " is a low effect of fear of COVID - 19," 17 to 26 "is a moderate effect of fear of COVID 19 " and " 27 to 35 " is a high effect of fear of COVID - 19, the higher the score the higher it will be the effect of fear about COVID - 19 in the disadvantaged population in SJL of Lima. ${ }^{16}$

We refer to a low effect of fear of COVID - 19 when the person feels the emotion of suspicion that they have been infected with COVID - 19 or a relative presents it, moderate effect of fear of COVID - 19 refers to the feeling of danger nearby to the person or family where they consider it a threat of contagion in them and a high effect on fear of COVID -19 , it is the feeling where people feel that they have the symptoms of COVID - 19 even though they have not been exposed.

3. CAS that includes 5 questions in which it represents in 4 dimensions: question 1 (cognitive), question 2 (behavioral), question 3 and 5 (emotional) and question 4 (physiological), in which it is valued with a standard scale Likert with 5 answer options: " $0=$ not at all", " $1=$ rare, less than one or two days", " $2=$ several days, " $3=$ more than 7 days" and " 4 = almost all days during the last two weeks", the higher the score in each dimension, the higher the level of anxiety due to coronavirus in the person, where the score $\geq 9$ is classified as people with dysfunctional anxiety associated with COVID-19 $1{ }^{17}$. We refer to dysfunctional anxiety where the mental health of the person is altered in an excessive way in any situation that considers dangerous.

The instrument's validity to measure anxiety due to COVID-19 was determined using the Kaiser-Mayer-Olkin sample adequacy measure obtained a coefficient of 0.791 (KMO> $0.5)$, while the Bartlett sphericity test obtained significant results $\left(\mathrm{X}^{2}\right.$ approx. $\left.=2731.798 ; \mathrm{gl}=10 ; \mathrm{p}=0.000\right)$.

The reliability of the instrument was determined based on Cronbach's alpha statistical test, the same one that obtained a coefficient of $0.921(\alpha>0.8)$ for all items $(i=5)$.

The instrument's validity to measure fear of COVID-19 was determined using the Kaiser-Mayer-Olkin sample adequacy measure obtained a coefficient of $0.837(\mathrm{KMO}>0.5)$, while the Bartlett sphericity test obtained significant results ( $\mathrm{X}^{2}$ approx. $=4676.440 ; \mathrm{gl}=21 ; \mathrm{p}=0.000)$.

The reliability of the instrument was determined based on Cronbach's Alpha statistical test, the same one that obtained for all the items $(i=7)$ a coefficient of $0.932(\alpha>0.8)$.

In this research, the data were analyzed by the SPSS statistical program to perform tabulations and figures. 


\section{Place and Application of the Instrument}

The virtual survey was carried out to measure the Fear and Anxiety of COVID-19 in a disadvantaged population in the San Juan de Lurigancho district of Lima, in which it was carried out in a vulnerable area, where they did not have basic water resources, electricity or sewage, most of the families live in poverty and extreme poverty, in addition to the fact that the members do not have stable jobs, only temporary and temporary jobs, but as a result of the COVID-19 pandemic, the population of the area where the study was carried out has become even more precarious.

Likewise, the virtual survey is based on the fear and anxiety that they present because of the COVID-19 pandemic, and how they can cope with this situation that compromises their health and the population in general.

\section{RESULTS}

Figure 1 shows anxiety due to COVID - 19, where 170 $(27.6 \%)$ of the participants present dysfunctional anxiety and $447(72.4 \%)$ of the participants do not present dysfunctional anxiety.

In Figure 2, it observes the fear of COVID - 19, where 275 $(44.6 \%)$ of the participants have a high effect of fear of COVID - 19, 254 (41.2\%) have a moderate effect of fear of COVID - 19 and 88 (14.3\%) have a low effect on fear of COVID -19

In Table 1, it observes the relationship between anxiety and fear of COVID - 19, where 235 (84.4\%) have a high-medium effect on fear of COVID - 19, also who do not have dysfunctional anxiety and $78(80.4 \%)$ have a high effect of fear of COVID - 19. also have dysfunctional anxiety. It was determined with Pearson's chi-square test $\left(\mathrm{X}^{2}\right)$. The level of significance of the test obtained a value of $15.15(\mathrm{p}>0.05)$ $\left(X^{2}=179.079 ; \mathrm{df}=3\right)$, also, the symmetric measurements of Pearson's R were made with a value of 0.260 , reflecting that the two variables have a positive correlation and the Spearman correlation with a value of 0.274 that reflects a positive correlation.

Figure 3 shows anxiety in relation to sex, where participants without dysfunctional anxiety are higher in 240 (53.7\%) females than 207 (46.3\%) males y 107 (62,9\%) females present dysfunctional anxiety, as well as $63(37.1 \%)$ of the male sex.

Figure 4 shows the fear of COVID-19 in relation to sex, where female participants presented a greater effect of fear of COVID-19, $200(72.7 \%)$ than in males $75(27.3 \%)$, $101(39,8 \%)$ of the female sex have a moderate fear of COVID - 19 and $153(60.2 \%)$ of the male sex have a moderate fear of COVID - 19, and $46(52.3 \%)$ of the female sex have a low effect of fear of COVID - 19 and in the male sex.
Table 2 shows the relationship of fear due to COVID-19 and the occupation of the study population. It was determined with Pearson's chi-square test $\left(\mathrm{X}^{2}\right)$. The level of significance of the test obtained a value of $1.25(\mathrm{p}>0.05)\left(\mathrm{X}^{2}=195.02\right.$; $\mathrm{df}=9$ ), also the symmetric measures of Pearson's $\mathrm{R}$ were performed with a value of $(\mathrm{R}=-0.111)$ reflecting that the two variables have a negative correlation, and the Spearman correlation with a value of $(-0.152)$ that reflects a strongly negative correlation.

Table 3 shows the relationship between anxiety due to COVID-19 and the occupation of the study population. It was determined with Pearson's chi-square test $\left(\mathrm{X}^{2}\right)$. The level of significance of the test obtained a value of $3.86(p>0.05)$ $\left(\mathrm{X}^{2}=39.273\right.$; df $\left.=3\right)$, also the symmetric measurements of Pearson's $\mathrm{R}$ were performed with a value of $(\mathrm{R}=0.139)$ reflecting that the two variables have a positive correlation, and the Spearman.

In Figure 5, anxiety by COVID-19 is observed in relation to the occupation, where the inhabitants with temporary work do not present dysfunctional anxiety 193 (75.1\%) followed by the stable workers $157(81.3 \%)$, without occupation 83 (54.2\%) and students $14(100 \%)$.

Figure 6 shows the relationship between fear of COVID-19 and occupation, where the population with stable employment has a high effect on fear of COVID-19 135 (69.9\%), followed by the population without occupation $82(53.6 \%)$ with a high effect of fear of COVID - 19 and finally, the population with temporary occupation $58(22.6 \%)$ presents a high effect of fear of COVID - 19.

These results are important in the study since they will show how the population is in their mental health with respect to fear and anxiety due to the COVID-19 pandemic.

\section{DISCUSSION}

In the present research work, it was made known from the perspective of the mental health of San Juan de Lurigancho district population, emphasizing the ability to cope with situations that compromise the health of them and their families during the COVID-19 pandemic.

In the results on anxiety due to COVID - 19, it was observed that the participants did not present dysfunctional anxiety, this is since the population has been proactively alert, that is, they have had as their main function to protect themselves. At the same time, they also come into conflict to be able to face dangerous situations due to the pandemic, where their solution capacities are improving. The authors argue that anxiety was a mediator for the person in relation to their emotional reactions, perception of threat and coping behaviors, where their effects on themselves were positive in the person in coping capacity faced with the situation due to the 
COVID-19 pandemic. ${ }^{16,17,18}$

In the results on the fear of COVID - 19, it was observed that the participants had a high effect on fear of COVID - 19, this is due to the fact that the population in the face of the existing health crisis due to COVID - 19, has impacted at the level mental health in them, where the number of infections and deaths has generated in the population nervousness, concern, fear not only of contagion but also that one of their relatives may be infected or die from COVID - 19. The authors refer that the factors that increase the risk of being afraid of COVID-19 is a concern in relation to confinement and social isolation, and not living with a family member who lives far from them, since they have a fear of catching it if they are away from home. ${ }^{19}$

In the variables of anxiety and fear of COVID - 19 in relation to sex, it was found that the female sex does not have dysfunctional anxiety but that fear of COVID - 19 is high, and this is since they present negative levels, both psychoaffective and emotional, related to fear, inhibition, insecurity, frustration, and failure, all this considerably affects the female sex because of the COVID-19 pandemic. They argue that psycho-emotional and affective factors play an important role in sex female because of the COVID-19 pandemic has generated in them, the decrease in their emotional regulation, compromising their resilience, coping capacity and optimism in the face of this disease. ${ }^{12}$

In the variable's anxiety and fear of COVID-19 in relation to the occupation of the population, we observe that most of the population does not present dysfunctional anxiety, this is since the population has adapted to preventive measures within the home, where face the dangerous situation due to the COVID-19 pandemic, in these circumstances the response capacity of people rises in situations that they find risky. The authors argue that the resolution capacity of adaptation to situations that generate a negative impact on health is due to anxiety, since in people anxiety may be desirable to increase their response capacities to any situation of danger either in itself or in a member of its family. ${ }^{20}$ In contrast to the fear of COVID - 19, the majority of the population with stable work has a high effect of fear of COVID - 19, this is mainly due to health workers, since they care for COVID-19 positive patients, this generates a negative impact on them since when they see high numbers of cases they attend, they feel the fear that they may be infected and arrive in the same way or they think that some of the people may be a relative of theirs. The authors argue that the fear that occurs in health workers is due to the tension that occurs in the workplace where the shortage of materials, the increase in patients to attend, the hours of work that are carried out for days, all of these are factors that compromise the worker and negatively affect their mental health. ${ }^{4}$

\section{CONCLUSIONS}

It is concluded that appropriate psychological interventions should be considered in the population, especially in those who need it most.

It is concluded that strategies should be sought to address the consequences on the population's mental health.

It must intervene in programs that prevent and eliminate the mental disorders that can generate the pandemic due to COVID - 19.

It is recommended to educate the population about COVID 19 and the consequences on mental health in the population.

The limitation in the research work is access to the families where the study was carried out, since the area was not very accessible to carry out the coordination with the families on the virtual survey, since sometimes the families were not at home, since they had to do their morning jobs to support the economy at home even if they do not have a stable job.

This study will benefit future research work since in our country, this study has not been carried out, therefore it will help to carry out more studies with both variables.

\section{Conflict of Interest}

The authors declare no conflict of interest.

\section{Funding Source}

This research work doesn't have Funding Sources

\section{ACKNOWLEDGMENT}

Authors acknowledge the immense help received from the scholars whose articles are cited and included in references of this manuscript. The authors are also grateful to authors / editors / publishers of all those articles, journals, and books from where the literature for this article has been reviewed and discussed.

\section{Author's Contributions}

Rosa PS: Conceived and designed the analysis, wrote the paper and translation.

Hernan MS: Collected the data, Performed the analysis.

Eduardo MS: Contact with the people for the survey taking, translation and contributed data.

\section{REFERENCES}

1. Ali I. The COVID-19 Pandemic: Making Sense of Rumor and Fear: Op-Ed. Med Anthropol Cross Cult Stud Heal Illn. 2020;39(5):376-379. 
2. Belén A. Fear, Anger and Stress in Medical DecisionMaking during the Covid-19 Outbreak. JournalsSagepub. 2020;2020(01):11-12.

3. Singh P, Singh S, Sohal M, Dwivedi Y, Kahlon K, Sawhney R. Psychological fear and anxiety caused by COVID-19: Insights from Twitter analytics. Asian J Psychiatr. 2020;54:102280.

4. Hu D, Kong Y, Li W, Han Q, Zhang X, Zhu L, et al. Frontline nurses' burnout, anxiety, depression, and fear statuses and their associated factors during the COVID-19 outbreak in Wuhan, China: A large-scale cross-sectional study. EClinical Medicine. 2020;24:100424.

5. Coelho C, Suttiwan P, Arato N, Zsido A. On the Nature of Fear and Anxiety Triggered by COVID-19. Front Psychol. 2020;11(7): 301.

6. Islam M, Ferdous M, Potenza M. Panic and generalized anxiety during the COVID-19 pandemic among Bangladeshi people: An online pilot survey early in the outbreak. J Affect Disord. 2020;276:30-37.

7. Pinchak C. Pandemia por coronavirus (COVID-19); sorpresa, miedo y el buen manejo de laincertidumbre en la familia. Arch Pediatr Urug. 2020;91(1):76-77.

8. Asmundson G, Taylor S. Coronaphobia: Fear and the 2019nCoV outbreak. J Anxiey Disord. 2020;70(1):3.

9. Benzel E. Emotional Health in the Midst of the Coronavirus Disease 2019 (COVID-19) Pandemic. World Neurosurg. 2020;138.

10. Valero N, Velez M, Duran A, Torres M. Afrontamiento del COVID-19: estres,miedo, ansiedad y depresion. Enferm Investig Investig Vinculacion, Docencia y Gest. 2020;5(3):63-70.

11. Rodríguez A, Pantaleón Y, Dios I, Falla D. Fear of COVID-19, Stress, and Anxiety in University Undergraduate Students: A Predictive Model for Depression. Front Psychol. 2020;11:591797.

ANXIETY FOR COVID- 19

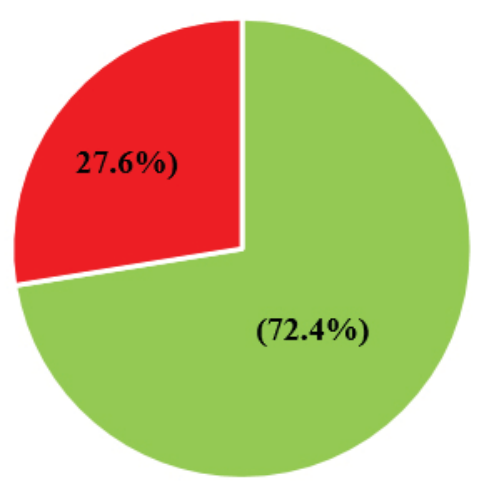

\section{- No dysfunctional anxiety - Dysfunctional anxiety}

Figure 1: Anxiety about COVID-19 in a disadvantaged population in the San Juan de Lurigancho district.
12. Bäuerle A, Teufel M, Musche V, Weismüller B, Kohler H, Hetkamp $\mathrm{M}$, et al. Increased generalized anxiety, depression and distress during the COVID-19 pandemic: a cross-sectional study in Germany. J Public Health (Oxf). 2020;42(1-7):672-678.

13. Hossain M, Jahid M, Amran K, Walton L, Uddin Z, Haque M, et al. Knowledge Attitudes and fear of COVID-19 during the Rapid Rise Period in Bangladesh. PLoS One. 2020;15(9):1-13.

14. Hetkamp M, Schweda A, Bäuerle A, Weismüller B, Kohler H, Musche V, et al. Sleep disturbances, fear, and generalized anxiety during the COVID-19 shut down phase in Germany: relation to infection rates, deaths, and German stock index DAX. Sleep Med. 2020;75:350-353.

15. Fernández $\mathrm{C}$, Baptista $\mathrm{P}$. Metodología de la Investigación. 6ta ed. México: Mc Graw-Hill/Interamericana.. 2015; 1-634

16. Ahorsu D, Lin C, Imani V, Saffari M, Griffiths M, Pakpour A. The Fear of COVID-19 Scale: Development and Initial Validation. Int J Ment Health Addict. 2020; 8(2):327

17. Lee S. Coronavirus Anxiety Scale: A brief mental health screener for COVID-19 related anxiety. Death Stud. 2020;44:1-9.

18. Cypryańska M, Nezlek J. Anxiety as a mediator of relationships between perceptions of the threat of COVID-19 and coping behaviors during the onset of the pandemic in Poland. PLoS One. 2020;15(10):1-16.

19. Wakashima K, Asai K, Kobayashi D, Koiwa K, Kamoshida S, Sakuraba M. The Japanese version of the Fear of COVID-19 scale: Reliability, validity, and relation to coping behavior. PLoS One. 2020;15(11):1-14.

20. McKay D, Yang H, Elhai J, Asmundson G. Anxiety regarding contracting COVID-19 related to interoceptive anxiety sensations: The moderating role of disgust propensity and sensitivity. J Anxiety Disord. 2020;73:102233.

\section{FEAR OF COVID - 19}

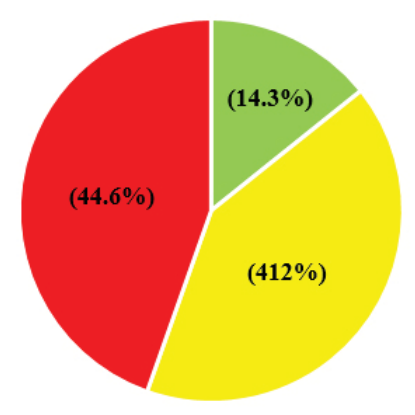

\footnotetext{
- Low effect on fear of COVID - 19

- Moderate effect on fear of COVID - 19

- High effect on fear of COVID - 19
}

Figure 2: Fear of COVID-19 in a disadvantaged population in the San Juan de Lurigancho district. 
Table 1: Relationship between Fear and Anxiety about COVID-19 in a disadvantaged population in the San Juan de Lurigancho district of Lima

\begin{tabular}{|c|c|c|c|c|c|}
\hline & & & \multicolumn{2}{|c|}{ Anxiety } & \multirow[t]{2}{*}{ Total } \\
\hline & & & No dysfunctional anxiety & Dysfunctional anxiety & \\
\hline \multirow[t]{8}{*}{ Fear } & Low effect & Count & 32 & 23 & 55 \\
\hline & & $\%$ within fear & $58.2 \%$ & $41.8 \%$ & $100.0 \%$ \\
\hline & Medium effect & Count & 161 & 27 & 188 \\
\hline & & \% within fear & $85.6 \%$ & $14.4 \%$ & $100.0 \%$ \\
\hline & High-medium effect & Count & 235 & 42 & 277 \\
\hline & & $\%$ within fear & $84.8 \%$ & $15.2 \%$ & $100.0 \%$ \\
\hline & High effect & Count & 19 & 78 & 97 \\
\hline & & $\%$ within fear & $19.6 \%$ & $80.4 \%$ & $100.0 \%$ \\
\hline \multirow[t]{2}{*}{ Total } & & Count & 447 & 170 & 617 \\
\hline & & $\%$ within fear & $72.4 \%$ & $27.6 \%$ & $100.0 \%$ \\
\hline
\end{tabular}

Chi-square tests

$\begin{array}{lccc} & \text { Value } & \text { df } & \begin{array}{c}\text { Asymptotic significance } \\ \text { (bilateral) }\end{array} \\ \text { Pearson's Chi-square } & & 3 & \text {.ooo } \\ \text { Likelihood ratio } & 179.079^{\mathrm{a}} & 3 & .000 \\ \text { Linear by linear association } & 165.253 & 1 & .000 \\ \text { N of valid cases } & 41.489 & & \end{array}$

a. o cells (o.o\%) have expected a count less than 5 . The minimum expected count is 15.15 .

Symmetric measurements

\begin{tabular}{cccc} 
Value & Asymptotic standard error & Approximate $\mathrm{T}^{\mathrm{b}}$ & $\begin{array}{c}\text { Approximate } \\
\text { significance }\end{array}$ \\
.260 & .047 & 6.664 & $.000^{\mathrm{c}}$ \\
.274 & .047 & 7.054 & $.000^{\mathrm{c}}$ \\
617 & & & \\
\hline
\end{tabular}

\begin{tabular}{|c|c|c|c|}
\hline $\begin{array}{l}\text { Interval by inter- } \\
\text { val }\end{array}$ & Pearson's R & .260 & .047 \\
\hline Ordinal by ordinal & $\begin{array}{l}\text { Spearman's cor- } \\
\text { relation }\end{array}$ & .274 & .047 \\
\hline \multicolumn{2}{|l|}{$\mathrm{N}$ of valid cases } & 617 & \\
\hline \multicolumn{4}{|c|}{ a. The null hypothesis is not assumed. } \\
\hline
\end{tabular}

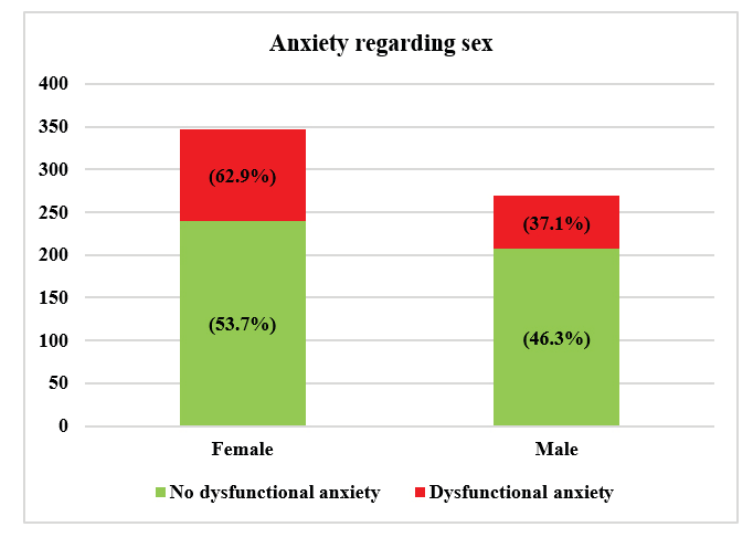

Figure 3: Anxiety in relation to sex in a disadvantaged population in the San Juan de Lurigancho district.

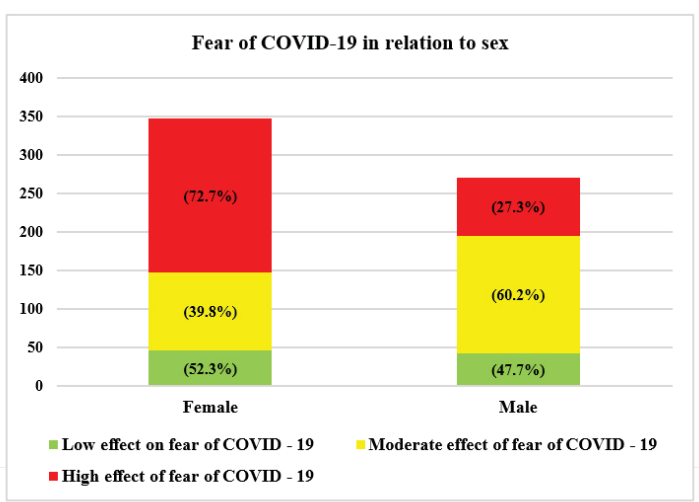

Figure 4: Fear of COVID-19 in relation to sex in a disadvantaged population in the San Juan de Lurigancho district. 
Table 2: Relationship between Fear of COVID-19 and Occupation in a disadvantaged population in the San Juan de Lurigancho district of Lima

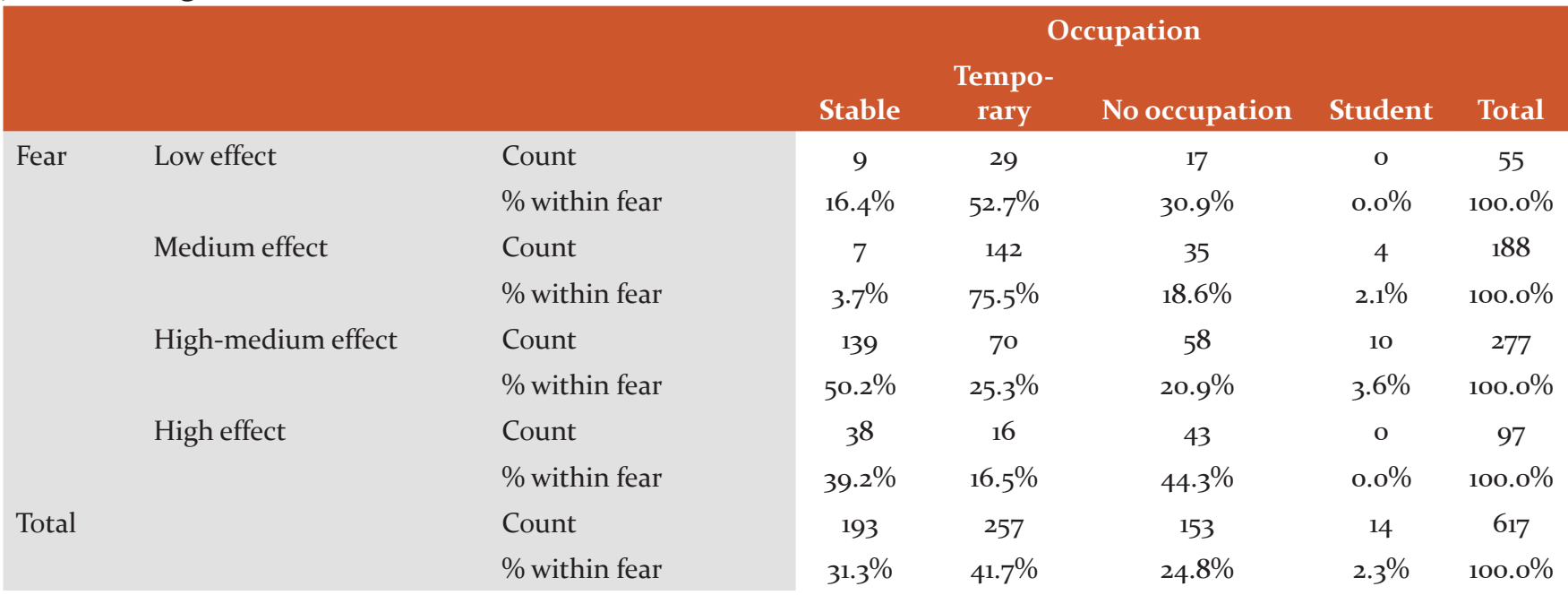

Chi-square tests

$\begin{array}{llll} & \text { Value } & \text { df } & \text { Asymptotic significa } \\ \text { Pearson's Chi-square } & 195.102^{\mathrm{a}} & 9 & 0.000 \\ \text { Likelihood ratio } & 216.672 & 9 & 0.000 \\ \text { Linear by linear association } & 7 \cdot 527 & 1 & 0.006 \\ \text { N of valid cases } & 617 & & \end{array}$

a. 3 cells $(18.8 \%)$ have expected a count less than 5 . The minimum expected count is 1.25 .

Symmetric measurements

\begin{tabular}{|c|c|c|c|c|c|}
\hline & & Value & $\begin{array}{l}\text { Asymptotic stand- } \\
\text { ard error }\end{array}$ & Approximate $\mathrm{T}^{\mathrm{b}}$ & $\begin{array}{l}\text { Approximate } \\
\text { significance }\end{array}$ \\
\hline Interval by interval & Pearson's R & -.111 & .037 & -2.758 & $.006^{c}$ \\
\hline Ordinal by ordinal & Spearman's correlation & -.152 & .042 & -3.825 & $.000^{c}$ \\
\hline $\mathrm{N}$ of valid cases & & & & & \\
\hline
\end{tabular}
a. The null hypothesis is not assumed.
b. Use of the asymptotic standard error that the null hypothesis assumes.
c. It is based on normal approximation.

Table 3: Relationship between Anxiety due to COVID-19 and Occupation in a disadvantaged population of the San Juan de Lurigancho district of Lima

\begin{tabular}{|c|c|c|c|c|c|}
\hline & & & \multicolumn{2}{|c|}{ Anxiety } & \multirow[t]{2}{*}{ Total } \\
\hline & & & $\begin{array}{l}\text { No dysfunctional } \\
\text { anxiety }\end{array}$ & $\begin{array}{c}\text { Dysfunctional } \\
\text { anxiety }\end{array}$ & \\
\hline \multirow[t]{8}{*}{ Occupation } & Stable & Count & 157 & 36 & 193 \\
\hline & & $\%$ within Occupation & $81.3 \%$ & $18.7 \%$ & $100.0 \%$ \\
\hline & Temporary & Count & 193 & 64 & 257 \\
\hline & & $\%$ within Occupation & $75.1 \%$ & $24.9 \%$ & $100.0 \%$ \\
\hline & No occupation & Count & 83 & 70 & 153 \\
\hline & & $\%$ within Occupation & $54.2 \%$ & $45.8 \%$ & $100.0 \%$ \\
\hline & Student & Count & 14 & o & 14 \\
\hline & & $\%$ within Occupation & $100.0 \%$ & $0.0 \%$ & $100.0 \%$ \\
\hline \multirow[t]{2}{*}{ Total } & & Count & 447 & 170 & 617 \\
\hline & & $\%$ within Occupation & $72.4 \%$ & $27.6 \%$ & $100.0 \%$ \\
\hline
\end{tabular}


Table 3: (Continued)

\begin{tabular}{|c|c|c|c|c|c|}
\hline & & & \multicolumn{2}{|c|}{ Anxiety } & \multirow[t]{2}{*}{ Total } \\
\hline & & & $\begin{array}{l}\text { No dysfunctional } \\
\text { anxiety }\end{array}$ & $\begin{array}{c}\text { Dysfunctional } \\
\text { anxiety }\end{array}$ & \\
\hline \multicolumn{6}{|l|}{ Chi-square tests } \\
\hline & & Value & df & \multicolumn{2}{|c|}{$\begin{array}{l}\text { Asymptotic significance } \\
\text { (bilateral) }\end{array}$} \\
\hline \multicolumn{2}{|l|}{ Pearson's Chi-square } & $39.273^{\mathrm{a}}$ & 3 & \multicolumn{2}{|c|}{0.000} \\
\hline \multicolumn{2}{|l|}{ Likelihood ratio } & 41.219 & 3 & \multicolumn{2}{|c|}{ ooo } \\
\hline \multirow{2}{*}{\multicolumn{2}{|c|}{$\begin{array}{l}\text { Linear by linear association } \\
\mathrm{N} \text { of valid cases }\end{array}$}} & 11.856 & 1 & \multicolumn{2}{|c|}{0.001} \\
\hline & & \multicolumn{2}{|l|}{617} & & \\
\hline \multicolumn{6}{|c|}{ a. 1 cells $(12.5 \%)$ have expected a count less than 5 . The minimum expected count is 3.86 . } \\
\hline \multicolumn{6}{|c|}{ Symmetric measurements } \\
\hline & & Value & $\begin{array}{l}\text { Asymptotic stand- } \\
\text { ard error }^{s}\end{array}$ & Approximate $\mathrm{T}^{\mathrm{b}}$ & $\begin{array}{l}\text { Approximate } \\
\text { significance }\end{array}$ \\
\hline Interval by interval & Pearson's R & .139 & .039 & $3 \cdot 474$ & $0.001^{c}$ \\
\hline $\begin{array}{l}\text { Ordinal by ordinal } \\
\mathrm{N} \text { of valid cases }\end{array}$ & Spearman's correlation & .183 & .039 & 4.629 & $0.000^{c}$ \\
\hline
\end{tabular}

a. The null hypothesis is not assumed.

b. Use of the asymptotic standard error that the null hypothesis assumes.

c. It is based on normal approximation.

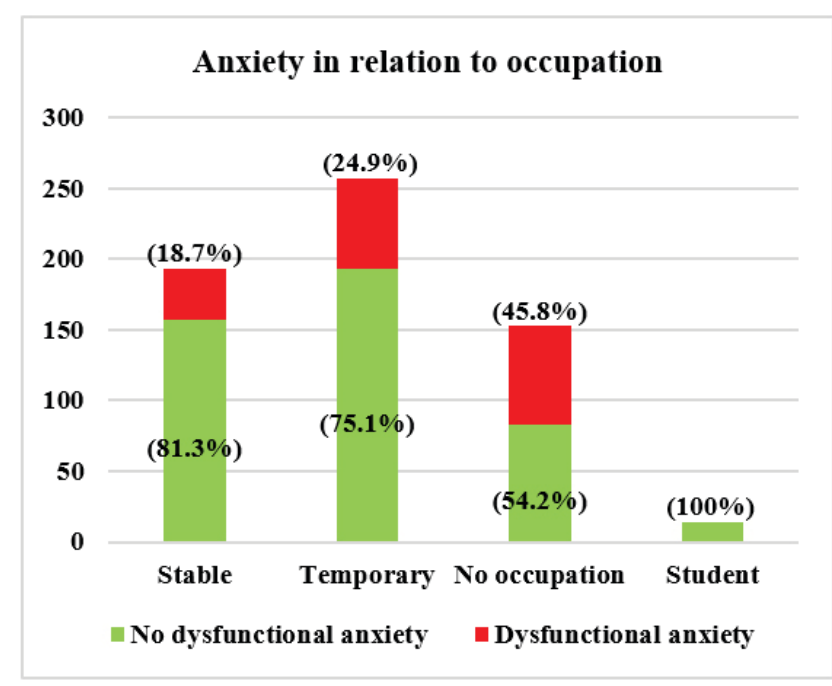

Figure 5: Anxiety in relation to employment in a disadvantaged population in the San Juan de Lurigancho district.

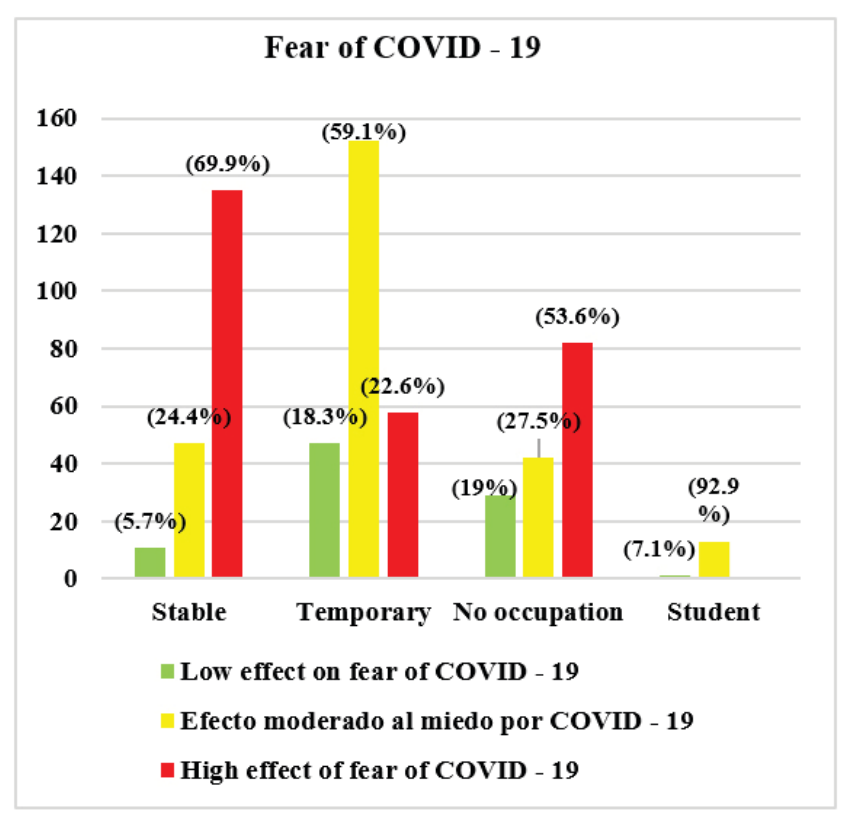

Figure 6: Fear in relation to occupation in a disadvantaged population in the San Juan de Luriganchodistrict. 